\title{
Landslide susceptibility mapping using knowledge driven statistical models in Darjeeling District, West Bengal, India
}

\author{
Jagabandhu Roy and Sunil Saha *i)
}

\begin{abstract}
Landslide is an important geological hazard in the large extent of geo-environment, damaging the human lives and properties. The present work, intends to identify the landslide susceptibility zones for Darjeeling, India, using the ensembles of important knowledge driven statistical technique i.e. fuzzy logic with Landslide Numerical Risk Factor (LNRF) and Analytical Hierarchical Process (AHP). In the study area, 326 landslides have been identified and a landslide inventory map has been prepared based on these landslides. The landslide inventory map has considered as the dependent factor and the geo-environmental factors like rainfall, slope, aspect, altitude, geology, soil texture, distance from river, lineament and road, land use/ land cover, NDVI and TWI have been considered as independent factors. Landslide susceptibility maps were prepared based on the Fuzzy- Landslide Numerical Risk Factor (LNRF) and Fuzzy- analytic hierarchy process (AHP) methods in a GIS environment. According to the results of LNRF and AHP based fuzzy logic 34 and 22\% areas are highly susceptible to landslide in this district. The landslide maps of both models have been validated through ROC curve and RMSE. The areas under curves are 91\% (for Fuzzy-LNRF) and 90\% (for Fuzzy-AHP) and RMSE values of these models are 0.18 and 0.14 which are indicating the good accuracy of both models in the identification of landslide susceptibility zones. Moreover, the Fuzzy-LNRF model is promising and sufficient to be advised as a method to prepare landslide susceptibility map at regional scale.
\end{abstract}

Keywords: Landslide numerical risk factor (LNRF), Fuzzy-AHP, Fuzzy logic (FL), Landslide susceptibility, GIS

\section{Introduction}

The mountainous areas of the world are frequently affected by the occurrences of the landslide because of high energy with variability and instability of masses (Gerrard 1994). From the environmental point of view, different kind of problems such as loss of soil fertility, acceleration of deforestation rate etc. may be caused by the landslides (Van Eynde et al. 2017). Most of the mountainous regions of India are characterized by the landslide disaster. A number of avalanche zones in the Indian Himalayan region are prominent, e.g. Jammu Kashmir, Himachal Pradesh, Kumayun, Darjeeling and Sikkim and North-eastern hilly states (Bhandari 2004). Landslide causes loss of property far greater than the any natural disaster (Turner and Schuster 1996; Garcia-

\footnotetext{
* Correspondence: sunilgeo.88@gmail.com

Department of Geography, University of Gour Banga, Malda, West Bengal, India
}

Rodriguez et al. 2008). Probably this rate of property damage will become more faster in the upcoming time in parity with the gradual development of urban centers, economic and rising regional rainfall due to climatic change in the landslide prone areas (Turner and Schuster 1996). Landslide occurrence is a significant barrier to the development in Darjeeling district. In Darjeeling district, landslides mainly take place due to heavy Monsoonal rainfalls and seismicity (Panikkar and Subramanyan 1996). The Darjeeling district had been experienced major landslides in July-August, 1993, May 2009 and September 2011 (Sarkar 1999). Massive rain caused landslides at Darjeeling town, Mirik, Kurseong and Kalimpong during June-July, 2015 and induced the loss of properties and lives. Reduction of effect of landslide can be possible only with a comprehensive knowledge about the probability of occurrence, character and magnitude of landslide in an area. Therefore, delineation of landslide vulnerable regions is indispensable for 
carrying out safer alleviation programs, and future planning of the area (Fan et al. 2019). In the present paper the main thrust has been given to delineate the landslide susceptible zones and chalk out suitable method.

Landslide is the major hazardous phenomenon which sometimes causes loss of human lives and properties. Therefore, any environmental factor may cause landslide when soil resistance power is lower than the shear force (Refahi 2000; Bouma and Imeson 2000). For landslide hazard evaluation several qualitative and quantitative methods have been used (Aleotti and Chowdhury 1999; Reichenbach et al. 2018). According to the qualitative method, the expert can evaluate the landslide susceptibility zones in his own opinion. The expert also can assess the vulnerable areas on the basis of similar geological and geomorphological character using the landslide inventory maps or existing landslide areas (Ayalew and Yamagishi 2005). The multi-criteria decision approach (MCDA) is an important way for indentifying the potential landslide areas using proper database. GIS based MCDA has been considered as the powerful techniques and procedures for evaluating, designing and accuracy judgments' of the results (Feizizadeh and Blaschke 2011, 2013). The present study has followed the GIS based MCDA techniques like Fuzzy-Landslide Numerical Risk Factor (LNRF) and Fuzzy-AHP for the landslide susceptibility mapping. Several other researchers applied Fuzzy-AHP and LNRF. Torkashvand et al. (2014) applied the Landslide Numerical Risk Factor (LNRF) model using GIS in East of the Sabalan volcanic mass region in Iran. Mokarram and Zarei (2018), Feizizadeh et al. (2014), Mosavi et al. (2017), Hejazi (2015), Mirnazari et al. (2015) and Hembram and Saha (2018) used Fuzzy-AHP model for their work and they got fruitful result for susceptibility mapping. Various statistical methods have been used by the researchers for analyzing the spatial pattern of landslides and preparing the landslide susceptible map such as logistic regression (Zêzere et al. 2017; Budimir et al. 2015), hierarchical approach (Youssef et al. 2014), statistical index (Dou et al., 2015), conditional analysis (Pourghasemi et al. 2012), weight of evidence Pradhan and Lee (2010). In the recent years, different machine learning techniques have also been used by some scholars for mapping the landslide disaster like decision tree (Pradhan 2013), random forest (Dou et al. 2019), artificial neural network Pradhan and Lee (2010), support vector machine (Tien Bui et al. 2012) etc. For identifying the landslide susceptibility zones, they used some important factors such as the elevation, lithology, slope, land use, river, topographical wetness index, aspect, road, fault, and precipitation maps. The rationale of this work is to identify the landslide susceptible areas using the ensemble models that are fuzzy- LRNF and Fuzzy-AHP of Darjeeling district and compare with them which have not been used in this district previously. The main advantage of ensemble of fuzzy logic and LRNF is that we can use both expert knowledge as well as statistical method for predicting landslide susceptibility using various causative factors.

In this study, remote sensing data along with meta data have been used to outline the landslide susceptibility areas for the Darjeeling District. Geo-environmental factors such as rainfall, slope, aspect, altitude, geology, soil texture, distance from river, distance from lineament, distance from road, land use/ land cover, normalized difference vegetation index (NDVI) and topographical wetness index (TWI) have been taken out to facilitate the quantification of landslide. Fuzzy-LRNF and Fuzzy-AHP have been applied considering the extracted database. Using the LRNF models, the fuzzy membership value has been calculated and thereafter, using the fuzzy gamma operator the membership values of parameters have been assembled for producing the landslides susceptible map of Darjeeling district. Similarly using the Fuzzy-AHP method, another map has also been produced. Finally, the maps have been verified and compared using known landslide locations based on ROC and RMSE quantitative validation methods. The main novelty is that the first time knowledge driven technique (Fuzzy logic) has been assembled with LRNF in this work to delineate the landslide susceptible zone of Darjeeling district and compared with the Fuzzy-AHP method. Moreover, according to the previous literatures so many researchers used LRNF and AHP method for mapping the landslide susceptibility but not a single researcher has used ensemble of fuzzy logic and LRNF model for predicting the spatial landslide probability and compared this ensemble method with fuzzy-AHP.

\section{Study area}

The Darjeeling district is located in the northernmost part of the West Bengal in India. It is an important mountainous part of the eastern Himalaya. Geographically the study area is extended between the latitudes $26^{\circ} 27^{\prime \prime}$ to $27^{\circ} 13^{\prime \prime} \mathrm{N}$ and longitudes $87^{\circ} 59^{\prime \prime} \mathrm{E}-88^{\circ} 53^{\prime \prime} \mathrm{E}$. The study area is covered with an area of 3149 sq.km (Fig. 1). According to the census of 2011, the total population of the district is $18,46,823$ with $9,37,259$ males and 9, 09,564 females. The population density of the district is 586 person $/ \mathrm{km}^{2}$ (District Statistical Handbook 2013). The number of rural households and the urban households of Darjeeling district was 212000 and 89584 in 2001, but these have increased to 236000 and 154540 in 2011 respectively (District Statistical Handbook 2011). The total length of national highway, state highway, major district road and other ordinary district road were 100, 80, 37 and $516 \mathrm{~km}$ respectively (District Gazetteer of Darjeeling District 1980). But the length of national 


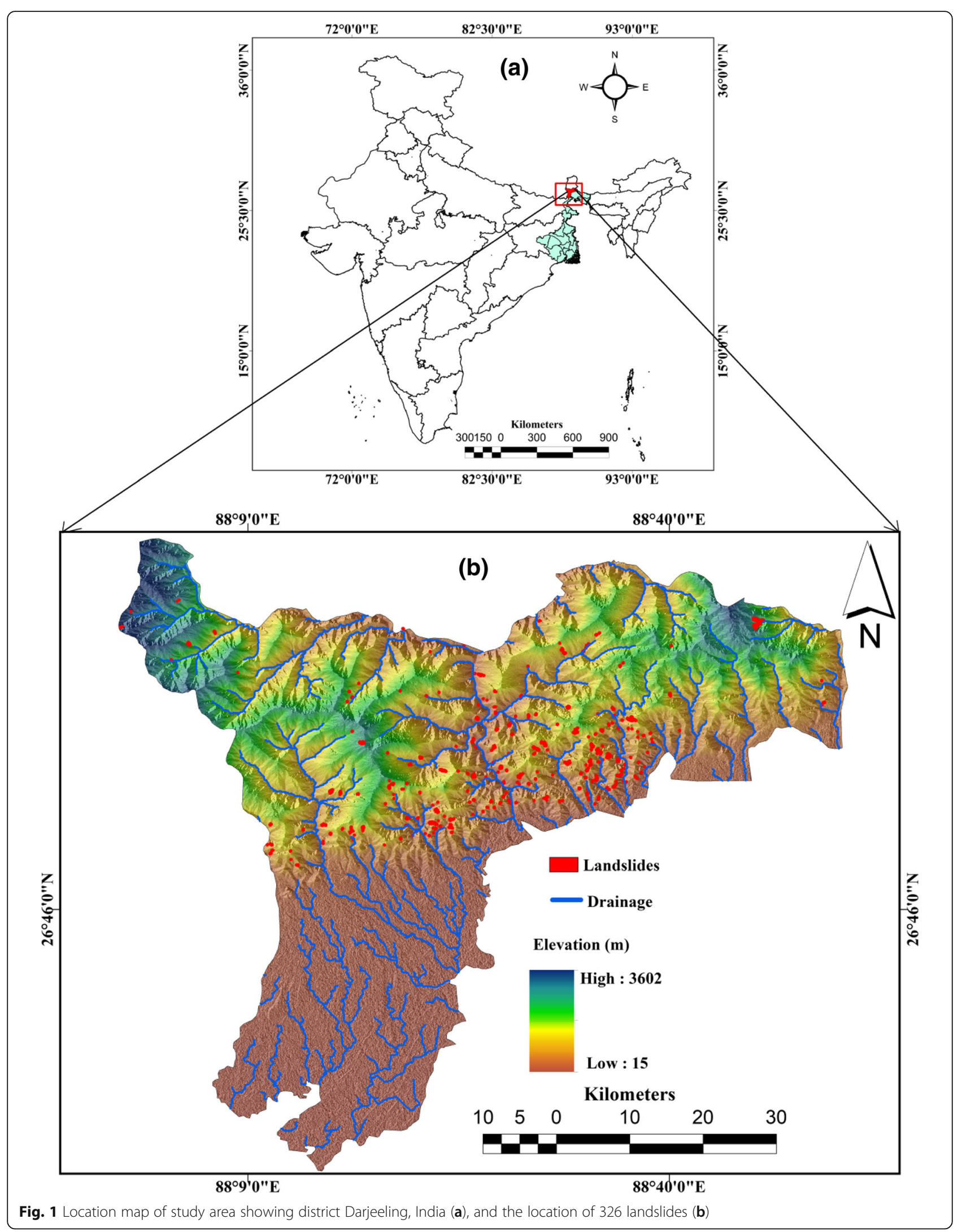


highway, state highway and main district highway have increased to 111, 191 and $79 \mathrm{~km}$ respectively in 2011 . The total length of surfaced and unsurfaced roads are $3696.54 \mathrm{~km}$ and $1652.51 \mathrm{~km}$ approximately in $2013-14$. The characteristics of both plain and mountainous topographies exit in this study area. The altitude of the study area ranges from $15 \mathrm{~m}$ to $3602 \mathrm{~m}$ from mean sea level and the slope from $0^{\circ}$ to $80^{\circ}$ approximately. The major portion of the study area is covered with Triassic rocks. The soil character of the study area is varied from one region to another region. The study area receives huge amount of rainfall in the monsoon season. The average annual rainfall of the study area is about 3051 $\mathrm{mm}$. The major rivers of the study area are Mahananda, Tista, Mechi, Balason, Jaldhaka, Rammam and Rangit, which are flowing from northern part. The district has some reputed eco-tourism sites and pilgrimage sites namely like Tiger Hill, Rock Garden, Mahakal Temple, Dhirdham Temple, Batasia Loop, Ghoom Monastery and Happy Vally Tea Garden, etc. Historically, Tea Plantation and Cinchona are the main sources of livelihood in the Darjeeling district. The community of the study area depends on the horticulture, tourism, and forestry. Siliguri is the major town of the study area which is familiar with 'gate way' of eastern India.

\section{Materials and methodology}

\section{Data sources}

For the fulfillment of the present work, various important data have been collected from different sources e.g. rainfall and temperature data from Indian Meteorological Department, population data from District
Statistical Handbook, Census of India 2011, drainage and road networks from Open series Topographical Sheets (2015), images and ASTER DEM from USGS Earth Explorer, Soil map from National Bureau of Soil Survey \& Land use Planning and Geological map from Geological Survey of India. The summery of the procedues followed is depicted in the flowchart (Fig. 2).

\section{Software used}

To predict the landslide potential areas, the thematic layers of selected geo-environmental parameters namely rainfall, slope, elevation, aspect, geology, soil texture, distance from lineament, distance from river, distance from road, natural differential vegetation index (NDVI) and TWI have been prepared with the help of ArcGIS 10.3.1, ENVI 4.7, GEOMATICA and the mathematical calculations have been done with the help of SPSS softwares.

\section{Preparation of landslide inventory map}

The landslide inventory map is the vital part for analyzing the landslide susceptibility, hazard and risk (Guzzetti et al. 2006). Pradhan and Lee (2009) and Pourghasemi et al. (2012) prepared the landslide inventory map for identifying the landslide hazards zones. Van Westen et al. (2000) remarked that the different data such as field investigations, historical landslide events and satellite image analysis can be used to prepare the landslide inventory map (Fig. 1b). In the present study, 326 landslides have been identified from Google earth imagery and multiple field visits. The landslide inventory map has been prepared in the GIS environment for

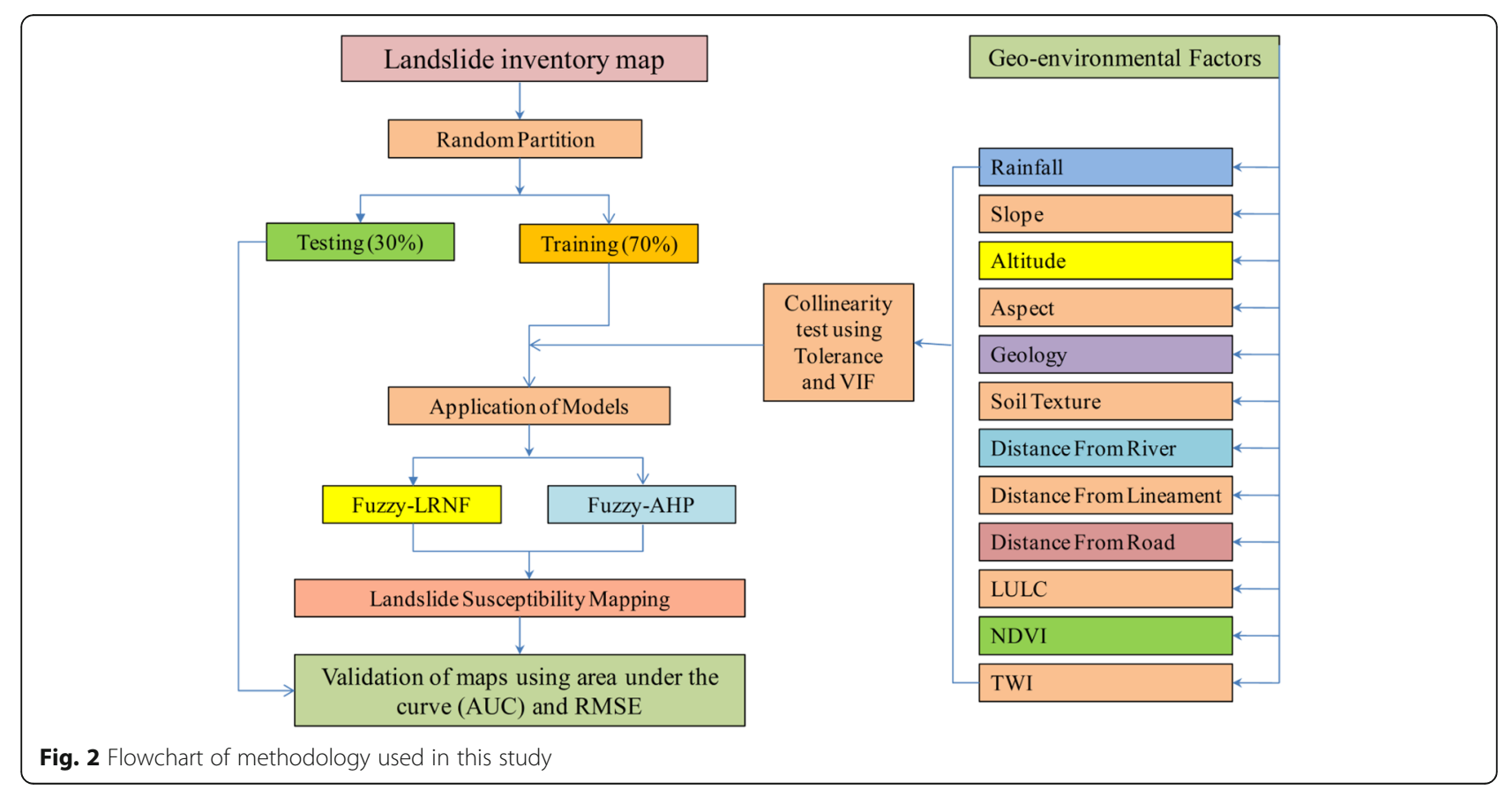


calculating the LNRF to predict the potentials landslide susceptibility areas in this district.

\section{Selection and Muliti-collinearity analysis of landslide causative factors}

There is a variety of geo-environmental parameters that have been used by the various researchers for producing the landslide susceptibility map. Still there is no standard guideline for selecting the landslide predictors. In this research 12 landslide causative factors i.e. rainfall, slope, aspect, altitude, geology, soil texture, distance from river, distance from lineament, distance from road, land use/ land cover, NDVI and TWI have been selected based on the multi-collinearity analysis for mapping the landslide susceptibility. In the landslide susceptibility analysis aforementioned causative factors are widely used (Dou et al. 2019; Arnone et al. 2016; Tien Bui et al. 2012).

Multi-collinearity analysis is an important way to verify the effectiveness of the landslide conditioning factors (Saha 2017). For the present study, the collinearity test of landslide determining factors has been done in the SPSS software. A tolerance of less than 0.10 and and variance inflation factors (VIF) 10 or above indicates multicollinearity problems (Dormann et al. 2012; Wang et al. 2008). In the present study, the values of tolerances and VIF of all the selected parameters are less than $10 \%$ (Table 1). So, there is no collinearity problem among the selected landslide determining factors.

\section{Preparation of thematic layers of selected parameters}

The average annual rainfall data of last 5 years, since 2012 to 2017 have been collected from Indian Meteorological Department. The thematic layer of rainfall has been prepared with the help of the interpolation method of IDW in GIS environment based on the average

Table 1 Collinearity statistics of landslide determining factors

\begin{tabular}{llll}
\hline Sl. & Parameters & \multicolumn{2}{l}{ Collinearity statistics } \\
\cline { 3 - 4 } No & & Tolerance & VIF \\
\hline 1 & Rainfall & 0.494 & 2.024 \\
2 & Elevation & 0.638 & 1.566 \\
3 & Slope & 0.894 & 1.118 \\
4 & Aspect & 0.742 & 1.348 \\
5 & Geology & 0.743 & 1.346 \\
6 & Soil & 0.858 & 1.166 \\
7 & Distance from River & 0.635 & 1.575 \\
8 & Distance from Lineament & 0.818 & 1.223 \\
9 & Distance from Road & 0.527 & 1.898 \\
10 & LULC & 0.833 & 1.201 \\
11 & NDVI & 0.804 & 1.243 \\
12 & TWI & 0.884 & 1.132 \\
\hline
\end{tabular}

annual rainfall data of last 5 years (Fig. 3a). The slope map of the study area has been prepared from ASTER DEM with the help of 3D analyst tool of ArcGIS 10.3.1 software (Fig. 3b). In case of elevation and aspect, these data layers have been prepared from ASTER DEM with the help of 3D analyst tool of surface in GIS environment (Fig. 3c, d).

The geology map has been prepared with the help of digitations process from referenced geological map which has been collected from Geological Survey of India (Fig. 3e).

The thematic layer of soil texture has been generated with the help of the digitations process form referenced soil map which has been collected from National Bureau of Soil Survey and Land Use Department (Fig. 3f). The distance from river and distance from road maps have been prepared with the help of Euclidian distance buffering tool in GIS environment (Fig. 3g, h). The lineament of the study area has been extracted from Landsat 8 OLI (Optical land Imager) image with the help of the ENVI 4.7 and GEOMATICA softwares. The distance from lineament map has been prepared with the help of Euclidian distance buffering tool of ArcGIS software 10.3.1 (Fig. 3i). The land use/ land cover (LULC) map has been prepared from Landsat 8 OLI imagery with the help of maximum likelihood classification method (Fig. 3j). The normalized differential vegetation index (NDVI) has been calculated from Landsat 8OLI image with the help of image analysis tool in ArcGIS 10.3.1 software (Fig. 3k). The thematic layer of TWI has been prepared from ASTER DEM imagery in GIS environment using Eq. 1 (Fig. 3l) which was suggested by Moore et al. (1991).

$$
T W I=\operatorname{In}\left(\frac{\alpha}{\tan \beta}\right)
$$

Where, TWI = topographic wetness index, $\alpha$ is cumulative upslope area draining through a point (per unit contour length), $\beta$ is the slope gradient (in degree). The minimum, maximum, categorical classification and methods of the selected geo-environmental conditional factors have been done in GIS environment and mentioned in the following Table 2.

\section{Fuzzy method}

For the present study, the Fuzzy method has been assembled with AHP and LNRF methods. The fuzzy maps of selected parameters have been prepared with the help of membership function (MF) tool in GIS environment. The membership function (MF) values range between 0 and 1 (Zadeh 1965). The value 0 means that $\mathrm{x}$ is not a member of the fuzzy set, while the value 1 means that $x$ is a full member of the fuzzy set. A sample of fuzzy set 


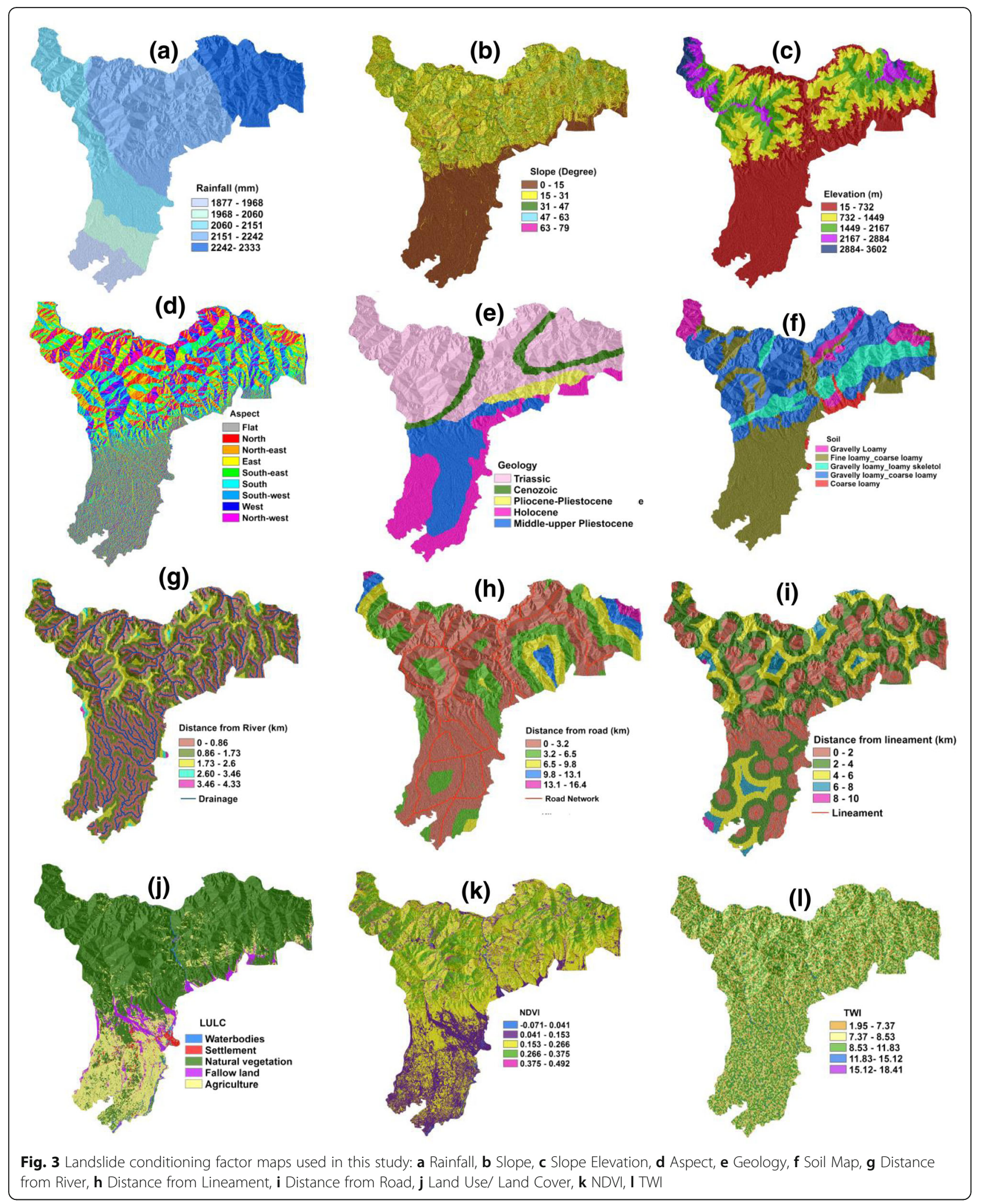


Table 2 Overview of selected parameters used for landslide susceptibility mapping

\begin{tabular}{|c|c|c|c|c|}
\hline \multirow[t]{2}{*}{ Parameters } & \multicolumn{2}{|c|}{ Ranges } & \multirow[t]{2}{*}{ Classes } & \multirow[t]{2}{*}{ Methods } \\
\hline & Min & $\operatorname{Max}$ & & \\
\hline \multirow[t]{5}{*}{ Rainfall (mm) } & 1877 & 2334 & 1. $1877.38-1991.9$ & Natural Break \\
\hline & & & 2. $1991.97-2090.54$ & \\
\hline & & & 3. $2090.45-2167.44$ & \\
\hline & & & 4. $2167.44-2239.06$ & \\
\hline & & & 5. $2239.06-2333.96$ & \\
\hline \multirow[t]{5}{*}{ Slope (Degree) } & 0 & 79.2 & 1. 0-9.32 & Natural Break \\
\hline & & & 2. $9.32-18.64$ & \\
\hline & & & 3. $18.44-27.34$ & \\
\hline & & & 4. $27.34-36.66$ & \\
\hline & & & 5. $5.36 .66-79.23$ & \\
\hline \multirow[t]{5}{*}{ Altitude (m) } & 15 & 3602 & 1. $15-422.93$ & Natural Break \\
\hline & & & 2. $422.93-985.6$ & \\
\hline & & & 3. $985.6-1576.4$ & \\
\hline & & & 4. $1576.4-2279.73$ & \\
\hline & & & 5. 5. $2279.73-3602$ & \\
\hline \multirow[t]{10}{*}{ Aspect } & - & - & 1. Flat $(-1)$ & Equal interval \\
\hline & & & 2. North $(0-22.5)$ & \\
\hline & & & 3. Northeast (22.5-67.5) & \\
\hline & & & 4. East (67.5-112.5) & \\
\hline & & & 5. Southeast (112.5-157.5) & \\
\hline & & & 6. South (157.5-202.5) & \\
\hline & & & 7. Southwest (202.5-247.5) & \\
\hline & & & 8. West (247.5-292.5) & \\
\hline & & & 9. Northwest (292.5-337.5) & \\
\hline & & & 10. north(337.5-360) & \\
\hline \multirow[t]{5}{*}{ Geology } & - & - & 1. Triassic & lithological units \\
\hline & & & 2. Cenozoic & \\
\hline & & & 3. Pliocene-Pleistocene, & \\
\hline & & & 4. Holocene & \\
\hline & & & 5. Middle-upper Pleistocene & \\
\hline \multirow[t]{5}{*}{ Soil texture } & - & - & 1. Gravelly loamy, & soil texture classes \\
\hline & & & 2. Fine loamy - Coarse Loamy & \\
\hline & & & 3. Gravelly loamy Skeletol & \\
\hline & & & 4. Gravelly Loam - Coarse Loamy & \\
\hline & & & 5. Coarse Loamy & \\
\hline \multirow[t]{5}{*}{ Distance from River (km) } & 0 & 4.33 & 1. $0-0.42$ & Natural Break \\
\hline & & & 2. $0.42-1.10$ & \\
\hline & & & 3. $1.10-1.66$ & \\
\hline & & & 4. $1.66-2.26$ & \\
\hline & & & 5. $2.26-4.33$ & \\
\hline \multirow[t]{5}{*}{ Distance from Lineament $(\mathrm{km})$} & 0 & 10.1 & 1. $0-1.54$ & Natural Break \\
\hline & & & 2. $1.54-2.85$ & \\
\hline & & & 3. $2.85-4.20,4$ & \\
\hline & & & 4. $4.20-5.75$ & \\
\hline & & & 5. $5.75-10.12$ & \\
\hline \multirow[t]{2}{*}{ Distance from Road (km) } & 0 & 16.5 & 1. $0-1.74$ & Natural Break \\
\hline & & & 2. $1.74-3.94$ & \\
\hline
\end{tabular}


Table 2 Overview of selected parameters used for landslide susceptibility mapping (Continued)

\begin{tabular}{|c|c|c|c|c|}
\hline \multirow[t]{2}{*}{ Parameters } & \multicolumn{2}{|c|}{ Ranges } & \multirow[t]{2}{*}{ Classes } & \multirow[t]{2}{*}{ Methods } \\
\hline & Min & $\overline{\operatorname{Max}}$ & & \\
\hline & & & 3. $3.94-6.72$ & \\
\hline & & & 4. $6.72-10.22$ & \\
\hline & & & 5. $10.22-16.49$ & \\
\hline \multirow[t]{5}{*}{ Land use/Land cover } & - & - & 1. Water bodies & supervised classification \\
\hline & & & 2. Vegetation & \\
\hline & & & 3. Fallow land & \\
\hline & & & 4. Agricultural land & \\
\hline & & & 5. Settlement & \\
\hline \multirow[t]{5}{*}{ NDVI } & -0.07 & 0.49 & 1. $-0.07-0.12$ & Natural Break \\
\hline & & & 2. $0.12-0.17$ & \\
\hline & & & 3. $0.17-0.23$ & \\
\hline & & & 4. $0.23-0.29$ & \\
\hline & & & 5. $0.29-0.49$ & \\
\hline \multirow[t]{5}{*}{ TWI } & 1.95 & 18.9 & 1. $1.95-7.37$ & Natural Break \\
\hline & & & 2. $7.37-8.53$ & \\
\hline & & & 3. $8.53-9.76$ & \\
\hline & & & 4. $9.76-11.70$ & \\
\hline & & & 5. $11.70-18.91$ & \\
\hline
\end{tabular}

is shown in the following equation (Mcbratney and Odeh 1997).

$$
\mathrm{A}=\left\{\mathrm{x}, \mu_{\mathrm{A}}(\mathrm{x})\right\} \text { for each } \mathrm{x} \varepsilon \mathrm{X}
$$

Where, $\mu_{\mathrm{A}}$ is the MF (membership of $\mathrm{x}$ in fuzzy set $\mathrm{A}$ ) so that:

If $\mathrm{x}$ does not belong to $\mathrm{A}$ then $\mu_{\mathrm{A}}=0$.

If $\mathrm{x}$ belongs completely to $\mathrm{A}$ then $\mu_{\mathrm{A}}=1$.

If $\mathrm{x} x$ belongs in a certain degree to $\mathrm{A}$ then

$$
0<\mu_{\mathrm{A}}(\mathrm{x})<1
$$

According to Eq. $3 \mathrm{MF}$ was used for rainfall, elevation, aspect, slope, NDVI, TWI [8].

$$
\mu_{A}(x)=f(x)=\left\{\begin{array}{ccc}
0 & x \leq a \\
x & -a / b-a & a \succ x<b \\
1 & x \geq b
\end{array}\right\}
$$

Where $\mathrm{x}$ is the input data and $\mathrm{a}, \mathrm{b}$ are the limit values. For geology, soil texture, distance from river, distance from lineament, LULC and distance from road the following MF has been used [4].

$$
\mu_{A}(x)=f(x)=\left\{\begin{array}{ccc}
0 & x \leq a \\
b & -x / b-a & a \succ x<b \\
1 & x \geq b
\end{array}\right\}
$$

\section{Fuzzy gamma operators}

Several fuzzy operators exist for combining membership functions such as AND, OR, SUM, PRODUCT and
GAMMA. In the present study, gamma operator has been used for combining membership functions.

Fuzzy gamma operation has been calculated using eqs. (5).

$$
\mu_{\gamma}=\left(\mu_{\text {sum }}\right) k^{\gamma} \cdot\left(\mu_{\text {product }}\right) \cdot{ }^{1-\gamma}
$$

The exponent $\gamma$, which is a number from $<0,1>$ interval, allows optimization of the membership combination. Setting it to the extremes of the interval give either fuzzy algebraic sum $(\gamma=1)$ or fuzzy algebraic product $(\gamma=0)$. To perform fuzzy gamma operation, several gamma operator $(k)$ values, i.e. $0.50,0.70,0.80,0.90,0.95$, and 0.975 are there. In the present study, fuzzy gamma operator $(\mathrm{k})$ value of 0.975 has been applied for producing the landslide susceptibility map.

\section{Landslide numerical risk factor (LNRF) model}

Landslide Numerical Risk Factor (LNRF) model is an important method for identifying the landslide hazard zones especially in the mountain region (Gupta and Joshi 1990). According to this model, the LNRF $>1$ value indicates that the geo-environmental factors have high responsibility for the occurrences of landslide. The LNRF $<1$ values represent that the geo-environmental factors are more stable and have less effect in landslides occurrences (Gupta and Joshi 1990). The LNRF has been calculated through Eq. (6): 
Table 3 Computation of LNRF model on landslide determining Factors

\begin{tabular}{|c|c|c|c|c|c|c|}
\hline \multirow[t]{2}{*}{ Parameters } & \multicolumn{2}{|l|}{ Area } & \multicolumn{2}{|c|}{ Landslides Area } & \multirow[t]{2}{*}{ LNRF } & \multirow{2}{*}{$\begin{array}{l}\text { Fuzzy } \\
\text { membership } \\
\text { values using } \\
\text { LNRF model }\end{array}$} \\
\hline & In Hectare & In Percentage & In Hectare & In Percentage & & \\
\hline \multicolumn{7}{|l|}{ Rainfall (mm) } \\
\hline Very Low (1877.38-1991.97) & 27659.36 & 8.78 & 0 & 0 & 0 & 0 \\
\hline Low (1991.97-2090.54) & 24856.96 & 7.89 & 0 & 0 & 0 & 0 \\
\hline Moderate (2090.45-2167.44) & 80967.44 & 25.71 & 31.56 & 7.32 & 0.37 & 0.11 \\
\hline High (2167.44-2239.06) & 114335.78 & 36.31 & 294.58 & 68.29 & 3.41 & 1.00 \\
\hline Very High (2239.06-2333.96) & 67080.46 & 21.3 & 105.21 & 24.39 & 1.22 & 0.36 \\
\hline \multicolumn{7}{|l|}{ Slope (Degree) } \\
\hline Very Low (0-9.32) & 101505.25 & 32.23 & 14.5 & 3.36 & 0.17 & 0.11 \\
\hline Low (9.32-18.64) & 58545.55 & 18.59 & 52.56 & 12.18 & 0.61 & 0.39 \\
\hline Medium (18.44-27.34) & 70795.02 & 22.48 & 103.31 & 23.95 & 1.2 & 0.76 \\
\hline High (27.34-36.66) & 57571.95 & 18.28 & 135.93 & 31.51 & 1.58 & 1.00 \\
\hline Very High (36.66-79.23) & 26482.23 & 8.41 & 125.06 & 28.99 & 1.45 & 0.92 \\
\hline \multicolumn{7}{|l|}{ Altitude (m) } \\
\hline Very Low (15-422.93) & 115880.61 & 36.8 & 35.17 & 8.15 & 0.41 & 0.16 \\
\hline Low (422.93-985.6) & 71784.89 & 22.8 & 224.01 & 51.93 & 2.6 & 1.00 \\
\hline Medium (985.6-1576.4) & 63320.09 & 20.11 & 81.46 & 18.88 & 0.94 & 0.36 \\
\hline High (1576.4-2279.73) & 44471.47 & 14.12 & 72.2 & 16.74 & 0.84 & 0.32 \\
\hline Very High(2279.73-3602) & 19442.94 & 6.17 & 18.51 & 4.29 & 0.21 & 0.08 \\
\hline \multicolumn{7}{|l|}{ Aspect } \\
\hline Flat $(-1)$ & 163.37 & 0.05 & 0 & 0 & 0 & 0 \\
\hline North (0-22.5) & 20317.92 & 6.45 & 7.41 & 1.72 & 0.09 & 0.07 \\
\hline North-East (22.5-67.5) & 39614.59 & 12.58 & 25.92 & 6.01 & 0.3 & 0.22 \\
\hline East (67.5-112.5) & 39009.88 & 12.39 & 59.24 & 13.73 & 0.69 & 0.51 \\
\hline South-East (112.5-157.5) & 44774.25 & 14.22 & 87.01 & 20.17 & 1.01 & 0.75 \\
\hline South (157.5-202.5) & 45083.47 & 14.32 & 116.63 & 27.04 & 1.35 & 1.00 \\
\hline South-West (202.5-247.5) & 39204.16 & 12.45 & 70.35 & 16.31 & 0.82 & 0.61 \\
\hline West (247.5-292.5) & 32441.32 & 10.3 & 49.98 & 11.59 & 0.58 & 0.43 \\
\hline North-West (292.5-337.5) & 35974.84 & 11.42 & 12.96 & 3 & 0.15 & 0.11 \\
\hline North (337.5-360) & 18316.21 & 5.82 & 1.85 & 0.43 & 0.02 & 0.01 \\
\hline \multicolumn{7}{|l|}{ Geology } \\
\hline Triassic & 166113.98 & 52.75 & 302.86 & 70.21 & 3.51 & 1 \\
\hline Cenozoic & 23200.35 & 7.37 & 82.6 & 19.15 & 0.96 & 0.27 \\
\hline Pliocene-Pleistocene & 11258.98 & 3.58 & 45.89 & 10.64 & 0.53 & 0.15 \\
\hline Holocene & 58152.53 & 18.47 & 0 & 0 & 0 & 0 \\
\hline Middle-upper Pleistocene & 56174.15 & 17.84 & 0 & 0 & 0 & 0 \\
\hline \multicolumn{7}{|l|}{ Soil texture } \\
\hline Gravelly loamy & 23549.04 & 7.48 & 68.11 & 15.79 & 0.79 & 0.46 \\
\hline Fine loamy Coarse Loamy & 126713.02 & 40.24 & 113.51 & 26.32 & 1.32 & 0.77 \\
\hline Gravelly loamy, Loamy Skeletal & 38586.66 & 12.25 & 147.57 & 34.21 & 1.71 & 1 \\
\hline Gravelly Loamy Coarse Loamy & 120449.25 & 38.25 & 90.81 & 21.05 & 1.05 & 0.61 \\
\hline Coarse Loamy & 5602.03 & 1.78 & 11.35 & 2.63 & 0.13 & 0.08 \\
\hline \multicolumn{7}{|l|}{ Distance from River (km) } \\
\hline $0-0.42 \mathrm{~km}$ & 99542.45 & 31.61 & 73.65 & 17.07 & 0.85 & 0.37 \\
\hline $0.42-1.10 \mathrm{~km}$ & 110752.04 & 35.17 & 199.89 & 46.34 & 2.32 & 1 \\
\hline $1.10-1.66 \mathrm{~km}$ & 64340.57 & 20.43 & 115.73 & 26.83 & 1.34 & 0.58 \\
\hline $1.66-2.26 \mathrm{~km}$ & 32920.37 & 10.45 & 42.08 & 9.76 & 0.49 & 0.21 \\
\hline
\end{tabular}


Table 3 Computation of LNRF model on landslide determining Factors (Continued)

\begin{tabular}{|c|c|c|c|c|c|c|}
\hline \multirow[t]{2}{*}{ Parameters } & \multicolumn{2}{|l|}{ Area } & \multicolumn{2}{|c|}{ Landslides Area } & \multirow[t]{2}{*}{ LNRF } & \multirow{2}{*}{$\begin{array}{l}\text { Fuzzy } \\
\text { membership } \\
\text { values using } \\
\text { LNRF model }\end{array}$} \\
\hline & In Hectare & In Percentage & In Hectare & In Percentage & & \\
\hline $2.26-4.33 \mathrm{~km}$ & 7344.58 & 2.33 & 0 & 0 & 0 & 0 \\
\hline \multicolumn{7}{|c|}{ Distance from Lineament $(\mathrm{km})$} \\
\hline $0-1.54 \mathrm{~km}$ & 81563.6 & 25.9 & 110.6 & 25.64 & 1.28 & 0.77 \\
\hline $1.54-2.85 \mathrm{~km}$ & 95262.67 & 30.25 & 44.24 & 10.26 & 0.51 & 0.31 \\
\hline $2.85-4.20 \mathrm{~km}$ & 77028.98 & 24.46 & 143.78 & 33.33 & 1.67 & 1.00 \\
\hline $4.20-5.75 \mathrm{~km}$ & 44870.1 & 14.25 & 99.54 & 23.08 & 1.15 & 0.69 \\
\hline $5.75-10.12 \mathrm{~km}$ & 16174.66 & 5.14 & 33.18 & 7.69 & 0.38 & 0.23 \\
\hline \multicolumn{7}{|l|}{ Distance from Road (km) } \\
\hline $0-1.74 \mathrm{~km}$ & 140275.58 & 44.55 & 88.48 & 20.51 & 1.03 & 0.67 \\
\hline $1.74-3.94 \mathrm{~km}$ & 84741.4 & 26.91 & 44.24 & 10.26 & 0.51 & 0.33 \\
\hline $3.94-6.72 \mathrm{~km}$ & 50166.43 & 15.93 & 66.36 & 15.38 & 0.77 & 0.50 \\
\hline $6.72-10.22 \mathrm{~km}$ & 27267.21 & 8.66 & 132.72 & 30.77 & 1.54 & 1.00 \\
\hline $10.22-16.49$ & 12449.37 & 3.95 & 99.54 & 23.08 & 1.15 & 0.75 \\
\hline \multicolumn{7}{|l|}{ Land use/Land cover } \\
\hline Water bodies & 3466.31 & 1.1 & 39.87 & 9.24 & 0.46 & 0.16 \\
\hline Vegetation & 227240.32 & 72.16 & 255.55 & 59.24 & 2.96 & 1.00 \\
\hline Fallow land & 14437.29 & 4.58 & 29 & 6.72 & 0.34 & 0.11 \\
\hline Agricultural Land & 65442.75 & 20.78 & 106.93 & 24.79 & 1.24 & 0.42 \\
\hline Settlement & 4313.33 & 1.37 & 0 & 0 & 0 & 0.00 \\
\hline \multicolumn{7}{|l|}{ NDVI } \\
\hline Very Low $(-0.07-0.12)$ & 37936.34 & 12.05 & 114.18 & 26.47 & 1.32 & 0.91 \\
\hline Low (0.12-0.17) & 83384.9 & 26.48 & 125.06 & 28.99 & 1.45 & 1.00 \\
\hline Medium (0.17-0.23) & 85506.39 & 27.15 & 96.06 & 22.27 & 1.11 & 0.77 \\
\hline High (0.23-0.29) & 70015.86 & 22.23 & 65.25 & 15.13 & 0.76 & 0.52 \\
\hline Very High (0.29-0.49) & 38056.51 & 12.09 & 30.81 & 7.14 & 0.36 & 0.25 \\
\hline \multicolumn{7}{|l|}{ TWI } \\
\hline Very Low (1.95-7.37) & 49986.44 & 15.87 & 63.12 & 14.63 & 0.73 & 0.35 \\
\hline Low (7.37-8.53) & 113766.56 & 36.13 & 178.85 & 41.46 & 2.07 & 1.00 \\
\hline Medium (8.53-9.76) & 93346.92 & 29.64 & 115.73 & 26.83 & 1.34 & 0.65 \\
\hline High (9.76-11.70) & 46923.5 & 14.9 & 73.65 & 17.07 & 0.85 & 0.41 \\
\hline Very High (11.70-18.91) & 10876.58 & 3.45 & 0 & 0 & 0 & 0 \\
\hline
\end{tabular}

$$
\operatorname{LNRF}=\frac{\mathrm{A}}{\mathrm{E}}
$$

Where A: landslide area in every unit, E: mean area of landslide in the whole unit.

The sub-parameters wise LNRF values have been calculated (Table 3). In the present study, fuzzy membership values have been allotted based on LNRF. To transform the LNRF values to Fuzzy membership values each sub-class has been divided by the maximum value of LNRF of individual parameter. The membership value ranges from 0 to 1 . The fuzzy membership values using LNRF model have been converted into a single layer to chalk out the landslide susceptibility zone using Fuzzy
Gamma operators (k) values of 0.975 in GIS environment.

\section{Analytic hierarchy process (AHP)}

Analytic hierarchy process is an important multi-criteria decision analysis (MCDA) method which can be applied for assigning the weights to the individual parameter (Saaty and Vargas 1998). AHP method is a pair wise comparison matrix. When the matrix is formed, the consistency ratio (CR) value ranges from 0 to 1 (Saaty 1980, 1990, 1994). To identify the potentiality index, general linear combination method can be performed with the help of AHP method (Malczewski 1999). The pair wise matrix has been formed with the help of the Saaty's (1980) fundamental scale (Table 4). In the present 
Table 4 Fundamental scale of Saaty's (1980)

\begin{tabular}{ll}
\hline Scale & Description \\
\hline 1 & Equal Importance \\
3 & Moderate Importance \\
5 & Strong Importance \\
7 & Very Strong Importance \\
9 & Absolute Strong Importance \\
$2,4,6,8$ & Intermediate values between the two adjacent judgments
\end{tabular}

case, the weight of parameters calculated based on AHP method has been combined with fuzzy logic to prepare landslide susceptibility map of the study area.

\section{Results}

\section{Application of fuzzy-LNRF model}

The spatial distribution of average annual rainfall of the study area ranges from $1877.38 \mathrm{~mm}$ to $2333.96 \mathrm{~mm}$ (Fig. 3a) respectively. The rainfall map has been categorized into five classes such as very low (1877 mm-1991 $\mathrm{mm})$, low $(1991 \mathrm{~mm}-2090 \mathrm{~mm})$, moderate $(2090 \mathrm{~mm}$ $2167 \mathrm{~mm})$, high $(2167 \mathrm{~mm}-2239 \mathrm{~mm})$ and very high (2239 mm-2333 mm) respectively. The high sub-class of rainfall with $36.31 \%$ area is covered the $68.29 \%$ landslides of the study area (Table 3). The LNRF values have been calculated and converted into fuzzy membership (FM) value. Here, high rainfall sub-class has attained the highest FM value i.e. 1, indicating the high risk of landslide than other sub-class of rainfall (Table 3). The spatially the slope of the study area ranges from 0 to $79.23^{\circ}$ (Fig. 3b). It has been classified into five categories such as very low $\left(0^{\circ}-9.32^{\circ}\right)$, low $\left(9.32^{\circ}-18.64^{\circ}\right)$, medium $\left(18.44^{\circ}-27.34^{\circ}\right)$, high $\left(27.34^{\circ}-36.66^{\circ}\right)$ and very high $\left(36.66^{\circ}-79.23^{\circ}\right)$ classes based natural break classification method in GIS environment. The high and very high slope classes are covered with $31 \%$ and $28 \%$ landslides area. The fuzzy membership values of these sub-classes are nearer to 1 , representing as high landslides risk areas. The altitude of the study area ranges from $15 \mathrm{~m}$ to $3602 \mathrm{~m}$ (Fig. 3c) respectively. The altitudinal map has been categorized into five classes such as very low $(15 \mathrm{~m}$ to $422.93 \mathrm{~m}$ ), low ( $422.93 \mathrm{~m}$ to $985.6 \mathrm{~m}$ ), medium (985.6 $\mathrm{m}$ to $1576.4 \mathrm{~m}$ ), high ( $1576.4 \mathrm{~m}$ to $2279.73 \mathrm{~m}$ ) and very high $(2279 \mathrm{~m}-3602 \mathrm{~m})$. The low elevation class is covered with $51.93 \%$ landslide area (Table 3). The fuzzy membership value of $422.93 \mathrm{~m}-985.6 \mathrm{~m}$ elevation range is 1 , representing higher landslide susceptibility than other sub-layers. Aspect of the study area has been classified into several categories such as flat, north, northeast, east, southeast, south, southwest, west and northwest. South sub-layer with $14.32 \%$ area is covered $27.04 \%$ landslide area. Geologically, the study area is composed of five geological segments namely Triassic, Cenozoic, Pliocene-Pleistocene, Holocene and Middle- upper Pleistocene (Fig. 3e). Triassic geological segment with $52.75 \%$ area is encompassed with $70.21 \%$ landslide area. According to the LNRF model using fuzzy logic, the Triassic geological segment has attained the maximum LNRF and fuzzy membership value. The other sub-layers of geological segment are indicating the less probability of landslide occurrence. Pedagogically, the region is composed with several soil textural classes namely Gravelly loamy, Fine Loamy to Coarse Loamy, Gravelly Loamy to Loamy Skeletal, Gravelly Loamy to Coarse Loamy and Coarse Loamy (Fig. 3f). The 34.21\% landslide areas are concentrated in Gravelly Loamy to Loamy skeletal soil texture class (Table 3) and the LNRF and fuzzy membership values are 1.71 and 1 , which are representing high risk of landslides. The distance from river map (Fig. $3 \mathrm{~g}$ ) has been classified into five classes such as $0-0.42 \mathrm{~km}, 0.42 \mathrm{~km}-1.10 \mathrm{~km}, 1.10 \mathrm{~km}-1.66$ $\mathrm{km}, 1.66 \mathrm{~km}-2.26 \mathrm{~km}$ and $2.26 \mathrm{~km}$ to $4.33 \mathrm{~km}$. The classes $0.42 \mathrm{~km}-1.10 \mathrm{~km}$ and $1.10 \mathrm{~km}-1.66 \mathrm{~km}$ of river buffering are covered with $46.34 \%$ and $26.83 \%$ landslide area (Table 3). The LNRF values of $0.42 \mathrm{~km}-1.10 \mathrm{~km}$ and $1.10 \mathrm{~km}-1.66 \mathrm{~km}$ sub-layers are 2.32 and 1.34 as well as fuzzy membership values of the same layers are 1 and 0.58 which are indicating high landslide susceptibility. The lineament distance map (Fig. 3h) has been classified into five buffer zones such as $0-1.54 \mathrm{~km}, 1.54 \mathrm{~km}$ $-2.85 \mathrm{~km}, 2.85 \mathrm{~km}-4.20 \mathrm{~km}, 4.20 \mathrm{~km}-5.75 \mathrm{~km}$ and $5.75 \mathrm{~km}-10.12 \mathrm{~km}$. The $2.85-4.20 \mathrm{~km}$ buffer zone has higher LNRF value (Table 3 ) than the other buffer zones. Road building activity in mountain areas is regarded as an infrastructure improvement, which may ground detrimental effects on slope steadiness; therefore, it can be helpful for delineating the prone areas to landslide occurrence. The buffer layer $6.72 \mathrm{~km}$ to $10.22 \mathrm{~km}$. distance area from road is covered $30.77 \%$ landslide area (Table 3 ). This road buffer class has attained the fuzzy membership value 1 . Other sub-layers of distance from road are showing the low to medium landslide susceptibility. The five type of land use classes have been identified in this study area namely water bodies, natural vegetation, sand, agricultural land and settlement with the help maximum likelihood classification method in GIS environment (Fig. 3j). The $72.16 \%$ area is covered with natural vegetation area in this district. The agricultural land and settlement areas are indicating less probability for the occurrence of landslide. Natural differential vegetation index (NDVI) is one of the important factors of environment. The value of the NDVI of the study area ranges from -0.07 to 0.49 (Fig. 3k) respectively. The NDVI map of the study area has been classified into five classes such as very low $(-0.07-$ $0.12)$, low (0.12-0.17), medium (0.17-0.23), high (0.23$0.29)$ and very high (0.29-0.49). According to LNRF model, the low sub-class of NDVI is attained the highest LNRF and fuzzy membership values i.e. 1.45 and 1 which are also 


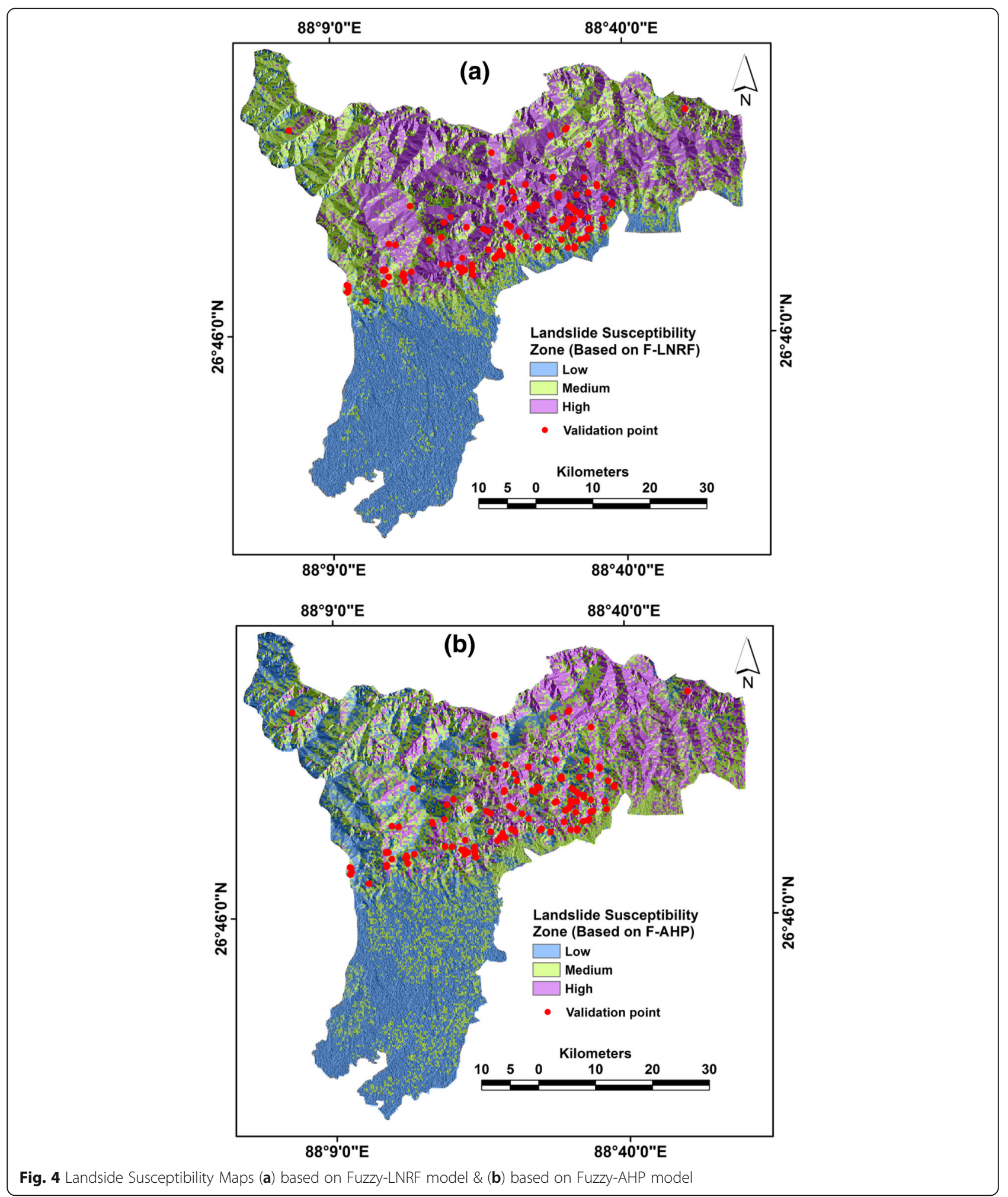

indicating the high landslide susceptibility. The spatial distribution of TWI of the study area ranges from 1.95 to 18.91(Fig. 3l) respectively. TWI map of the study area has been classified into five classes namely very low (1.95 to
7.37), low (7.37-8.53), medium (8.53-9.76), high (9.76$11.70)$ and very high (11.70-18.91) (Table 4). The low and medium TWI classes area representing the high risk for landslide than other sub-layers. 
The landslide susceptibility map (LSM) based on fuzzy membership values has been prepared with the help of fuzzy gamma operators $(\mathrm{k})$ value of 0.975 and shown in Fig. 4a. It has been classified into three classes namely low, medium and high landslide susceptibility zones. Out of the total district $34 \%$ area is highly susceptible to landslide (Table 6).

\section{Application of fuzzy-AHP model}

In the present work the Fuzzy set theory with AHP is considered as the multi-criteria decision approach for identifying the landslide susceptibility zones. The integration of fuzzy set theory and AHP can be provided a good and reliable technique for zoning landslide susceptibility. AHP is a single process which helps to determine the weight of different factors based on the expert's opinion and knowledge. For the present work, weights have been assigned to landslide determining factors (Table 5) with the help of AHP method. The highest weight has been assigned to rainfall $(0.180)$ and followed by slope (0.162), distance from the river (0.108), soil texture (0.095) and elevation (0.086) for mapping the landslide probability. Thereafter, the linear membership function (MF) has been used to prepare the fuzzy map of the selected parameters for landslide susceptibility mapping. The value of fuzzy membership ranges from 0 to 1 . Therefore, values of prepared fuzzy maps of all selected parameters must be ranged from 0 to 1 . The weights of parameters, calculated by AHP method, have been integrated with fuzzy maps of selected parameters to generate a single layer of landslide susceptibility with the help of raster calculator of spatial analyst tool in ArcGIS10.3.1 software. The landslide susceptibility map (Fig. 4b) has been classified into three categories like low, medium and high landslide susceptibility zones covering an area of $37.88 \%, 39.29 \%$ and $22.83 \%$ respectively (Table 6).

Some landslides identifed from google earth imagery and directly from the field are mentioned below- (Fig. 5)

\section{Validation}

The landslide susceptibility maps of Darjeeling district, prepared by Fuzzy-LNRF and Fuzzy-AHP models have been validated through the ROC curve and RMSE. Model based work may be possible to evaluate and justify easily with the help of ROC curve (Chung and Fabbri 2003). The ROC curve is drawn by $X$ and $Y$ axis. The $\mathrm{X}$ axis represents the false positive rate (1-specificity) and the $\mathrm{Y}$ axis represents the true positive rate (sensitivity) (Negnevitsky 2002). Mallick et al. (2018) and Feizizadeh et al. (2014) have applied the ROC curve for the validation of the landslide susceptibility zone. In the present study, 98 landslide patches have been selected among the 326 landslide patches for validating the landslide susceptibility maps. The area under curve (AUC) can be drawn for the landslide susceptibility zones with the help of the Table 7. According to the results of ROC curve, the area under curve (AUC) values of landslide susceptibility maps, prepared by the Fuzzy-LNRF and Fuzzy-AHP models are 91\% and $90 \%$ which are indicating the excellent potentiality of these models for landslide susceptibility mapping (Fig. 6a, b). The LSM of both models have also been

Table 5 Parameters wise weights, matrix and consistency ratio using AHP

\begin{tabular}{|c|c|c|c|c|c|c|c|c|c|c|c|c|c|}
\hline Parameters & Rainfall & Slope & Elevation & Aspect & Geology & $\begin{array}{l}\text { Soil } \\
\text { Texture }\end{array}$ & $\begin{array}{l}\text { Distance } \\
\text { from River }\end{array}$ & $\begin{array}{l}\text { Distance from } \\
\text { lineament }\end{array}$ & $\begin{array}{l}\text { Distance } \\
\text { from Road }\end{array}$ & LULC & NDVI & TWI & Weights \\
\hline Rainfall & 1 & & & & & & & & & & & & 0.180 \\
\hline Slope & 0.5 & 1 & & & & & & & & & & & 0.162 \\
\hline Elevation & 0.33 & 0.2 & 1 & & & & & & & & & & 0.086 \\
\hline Aspect & 0.2 & 0.5 & 1 & 1 & & & & & & & & & 0.084 \\
\hline Geology & 0.5 & 0.5 & 0.5 & 2 & 1 & & & & & & & & 0.080 \\
\hline Soil Texture & 0.5 & 0.2 & 2 & 1 & 0.5 & 1 & & & & & & & 0.095 \\
\hline $\begin{array}{l}\text { Distance from } \\
\text { River }\end{array}$ & 0.2 & 0.2 & 0.5 & 0.5 & 0.2 & 0.5 & 1 & & & & & & 0.108 \\
\hline $\begin{array}{l}\text { Distance from } \\
\text { lineament }\end{array}$ & 0.2 & 0.2 & 0.5 & 0.5 & 0.5 & 0.2 & 0.5 & 1 & & & & & 0.046 \\
\hline $\begin{array}{l}\text { Distance from } \\
\text { Road }\end{array}$ & 0.5 & 0.2 & 0.5 & 1 & 0.5 & 0.5 & 2 & 2 & 1 & & & & 0.062 \\
\hline LULC & 0.17 & 0.2 & 0.5 & 0.2 & 0.5 & 0.5 & 0.5 & 0.5 & 0.5 & 1 & & & 0.051 \\
\hline NDVI & 0.2 & 0.2 & 0.2 & 0.2 & 0.2 & 0.2 & 0.2 & 0.2 & 0.2 & 2 & 1 & & 0.025 \\
\hline TWI & 0.14 & 0.2 & 0.2 & 0.2 & 0.2 & 0.2 & 0.2 & 0.2 & 0.5 & 2 & 1 & 1 & 0.021 \\
\hline
\end{tabular}

Consistency Ratio $=0.078$ 
Table 6 Areal distributions of LSM based on LNRF and FuzzyAHP models

\begin{tabular}{|c|c|c|c|c|}
\hline \multirow{2}{*}{$\begin{array}{l}\text { Landslide } \\
\text { susceptibility } \\
\text { zones }\end{array}$} & \multicolumn{2}{|l|}{ LNRF model } & \multicolumn{2}{|c|}{ Fuzzy-AHP model } \\
\hline & Area in sq. km & $\%$ of Area & Area in sq.km & $\%$ of Area \\
\hline Low & 950.15 & 30.17 & 1192.97 & 37.88 \\
\hline Medium & 1114.40 & 35.39 & 1237.17 & 39.29 \\
\hline High & 1084.46 & 34.44 & 718.86 & 22.83 \\
\hline
\end{tabular}

validated through RMSE method. The RMSE is calculated using the Eq.7.

$$
\text { RMSE }=\sqrt{\frac{\sum_{i=1}^{N}(\mathrm{P}-\mathrm{A})^{2}}{\mathrm{~N}}}
$$

Where, $\mathrm{N}$ is the numbers of samples, $\mathrm{A}$ is the observed values and $\mathrm{P}$ is the predicted values. Can et al. (2005) has considered the RMSE value of 0.5 , as the cutoff value. The values of RMSE $>0.5$ and $<0.5$, indicate the bad predictive and good predictive model. In the
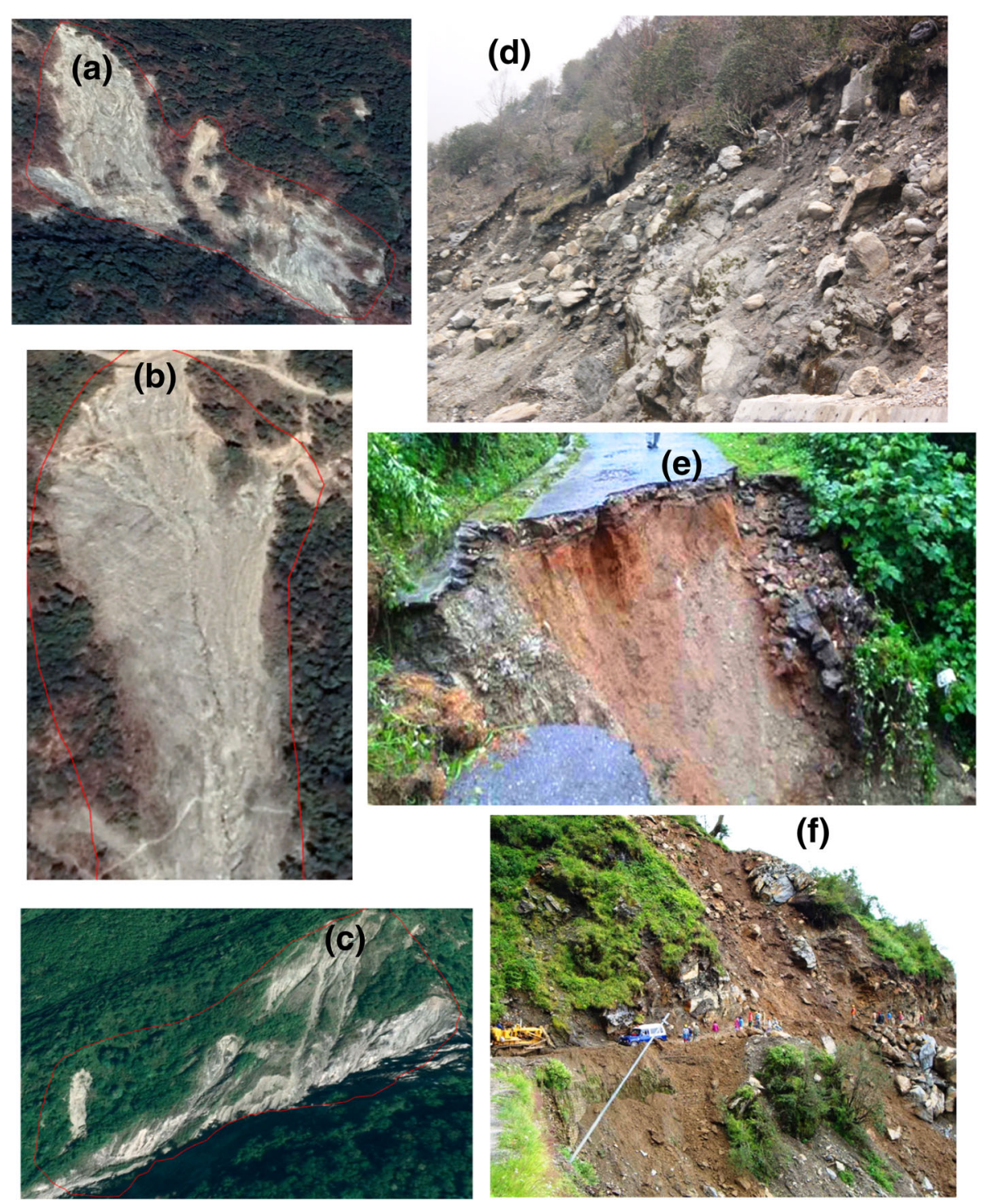

Fig. 5 Picture showing the landslide sites - from the google earth image. a Lish catchment $\left(26^{\circ} 57^{\prime} \mathrm{N}, 88^{\circ} 30^{\prime} 17^{\prime \prime} \mathrm{E}\right)$, b Nimbong Khasmahal $\left(26^{\circ} 58^{\prime} 04^{\prime \prime} \mathrm{N}, 88^{\circ} 34^{\prime \prime} 16^{\prime \prime} \mathrm{E}\right)$, c Sittong $\left(26^{\circ} 52^{\prime} \mathrm{N}, 88^{\circ} 22^{\prime} 30^{\prime \prime} \mathrm{E}\right)$ and from the field, $\mathbf{d}$ Near Kurseong town $\left(26^{\circ} 55^{\prime} 46.32^{\prime \prime} \mathrm{N}, 88^{\circ} 19^{\prime} 50.38^{\prime \prime} \mathrm{E}\right)$, e Near Darjeeling town (26ำ $\left.53^{\prime} 13.37^{\prime \prime} \mathrm{N}, 88^{\circ} 17^{\prime} 46.45^{\prime \prime} \mathrm{E}\right)$, f Nathula road (26 $\left.54^{\prime} 43.14^{\prime \prime} \mathrm{N}, 88^{\circ} 18^{\prime} 21.10^{\prime \prime} \mathrm{E}\right)$ 
Table 7 Characteristics of AUC of ROC curve (Yesilnacar 2005)

\begin{tabular}{ll}
\hline AUC Values & Characters \\
\hline $0.6-0.5$ & Average \\
$0.7-0.6$ & Good \\
$0.8-0.9$ & Very Good \\
$1-0.9$ & Excellent \\
\hline
\end{tabular}

present study, the results of RMSE are justified FuzzyLNRF $($ RMSE $=0.14)$ and Fuzzy-AHP $($ RMSE $=0.18)$ models as good predicative models for landslides susceptibility mapping.

\section{Discussions}

In the landslide prone areas appropriate methods of landslide susceptibility mapping play significant task in providing a proper approach to authorities and decision makers. Very fundamental information regarding the landslide conditioning factors can be acquired from the landslide susceptibility mapping (LSM) and it can be an essential way in hazard mitigation measures and management. There is a large number of weight combining methods for preparing the landslide susceptibility map. The results of some multi-criteria decision analysis such as AHP, LNRF, Fuzzy logic, Artificial Neural Network Support Vector Machine, Logistic Regression and Frequency Ratio are a little bit varied from region to region. Some researchers such as, Malik et al. (2016), Mohammadi et al. (2014), Shadfar et al. (2011) and Gupta and Joshi (1990) pointed out that LNRF method is suitable method in landslide susceptibility mapping. On the other hand, Abedini and Tulabi (2018) was indicated that LNRF is not suitable method like frequency ratio and AHP.
In this work, Fuzzy-AHP and Fuzzy-LNRF, the two efficient and easily operate ensemble models have been used for delineating landslide susceptibility and compared with them. In these two ensemble models FuzzyAHP and Fuzzy-LNRF, input process, calculations and output process are very simple and can be readily understood. The geo-environmental factors like slope, aspect, altitude, geology, soil texture, distance from river, distance from lineament, distance from road, rainfall, land use/ land cover, NDVI and TWI have been considered for the determination of the landslide susceptible area of the Darjeeling district. According to the Fuzzy-LNRE and Fuzzy-AHP maps $34.44 \%$ and $22.83 \%$ areas (Fig. 7 a and $b$ ) of the district fall under the high susceptibility of landslide. Based on these findings, it can be acknowledged that the high susceptibility zone delineated by the Fuzzy-LNRF method is forecasting greater percentage of the landslide area. Additionally, the reliability of the results of two susceptibility maps has been validated based on the known landslide dataset by employing the area under the curve (AUC) of the receiver operating characteristics (ROC) and RMSE. A landslide inventory map has been prepared considering the multiple field works and Google Earth Images. Out of the 326 landslides 246 (70\%) locations have been used for training data and remaining $80(30 \%)$ have been used as testing data. Respective AUC values of $91 \%$ and $90 \%$ for fuzzy-LRNF and fuzzy-AHP proved that the map produced by the fuzzy-LRNF model looks like having a better accuracy than the fuzzy-AHP model. This finding is helpful for emergency situation because time is very significant in hazard studies. It could be assessed that the models applied have relatively similar accuracies. Methods such as LNRF (Gupta and Joshi 1990 \& Abedini and Tulabi 2018) and fuzzy-AHP (Roodposhti et al. 2014) were used

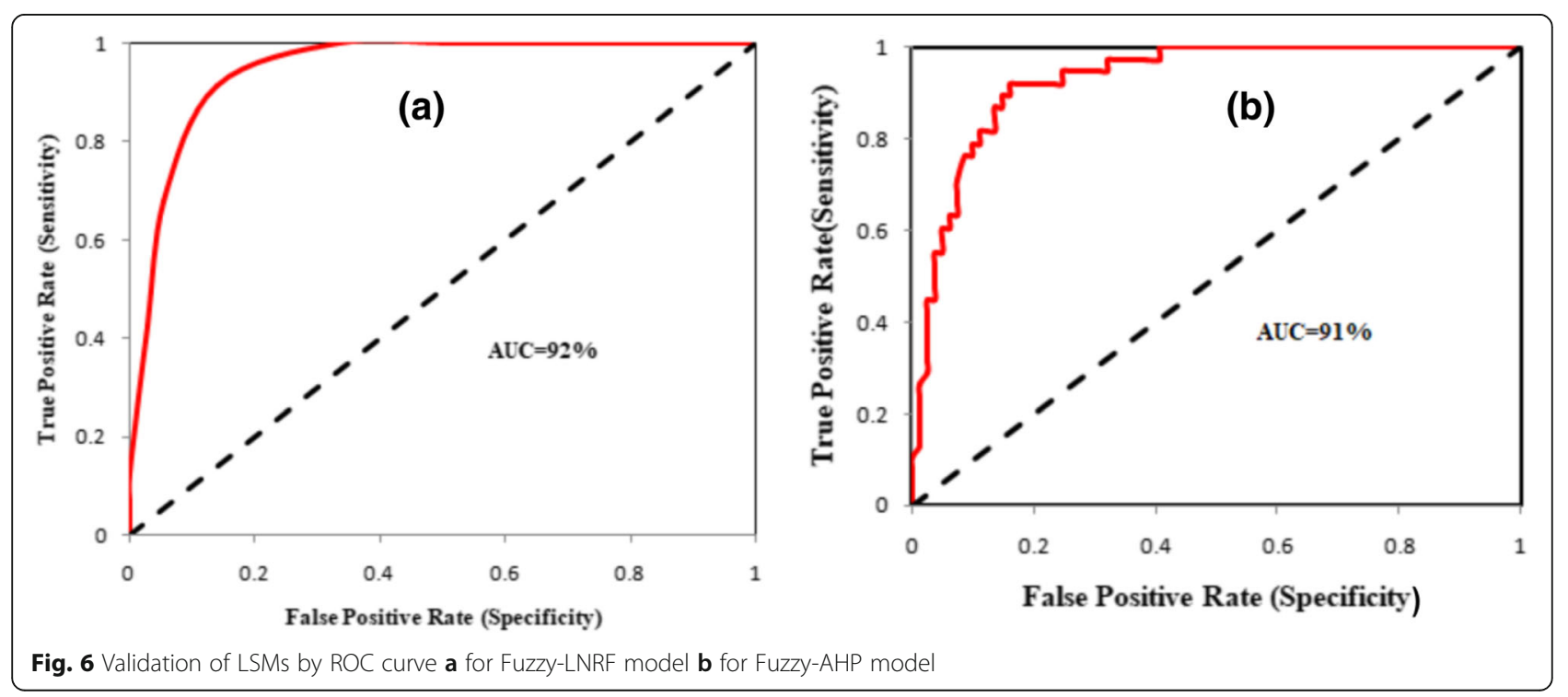






Fig. 7 Graph showing the distribution of area under different susceptibility classes a Percentage of area and $\mathbf{b}$ Area in sq.km

in mapping the landslide susceptibility. Compared to these previous studies the used methods i.e. fuzzy-LNRF and Fuzzy-AHP in this study are showing better performance in preparing the LSM. Taking into account the performances, we suggest that both Fuzzy-LNRF and Fuzzy-AHP models can be used in landslide studies, as they are capable of producing flawless and stable landslide susceptible maps for mitigating the risk and management planning. There are little differences in result between the Fuzzy-LNRF and Fuzzy-AHP derived susceptibility maps. Moreover, the Fuzzy-LNRF model is promising and sufficient to be advised as a method to prepare landslide susceptibility map at regional scale.

\section{Conclusions}

For the prevention of human lives and property, a short and long-term solution is necessary for mitigating the landslide risk in this region. At present day, landslide is to be considered the most serious natural hazards in the Darjeeling district. The study has been adopted the suitable multi-criteria decision making approaches like Fuzzy-AHP and Fuzzy-LNRF to outline the landslide susceptibility zones. The landslide susceptibility maps of both models have been categorized into three classes such as low, moderate and high landslide susceptibility zones. The high landslide susceptibility zone has been found in the middle and northern portions of the study area because of the presence of fragile soil, high concentration of drainage, frequent heavy rainfall and sloppy land. Among these two ensemble models, Fuzzy-LNRF is showing better acceptability than the other model. So, the study has been done by these two ensemble models help to understand the landslide hazards problem of an area. The study also provides the essential information to the planner, government, local people and researchers to take suitable steps for the reduction and the mitigation of the landslides problems in the Darjeeling district.

\section{Abbreviations}

AHP: Analytical hierarchical process; ASTER: Advanced space borne thermal emission and reflection radiometer; DEM: Digital elevation map;

GIS: Geographical information system; LNRF: Landslide Numerical Risk Factor;
LSM: Landslide susceptible map; LULC: Land use/Land cover; MCDA: Multicriteria decision approach; MF: Membership function; NDVI: Normalized differential vegetation index; OLI: Operational land imager; RMSE: Root mean square error; ROC: Receiver operating characteristic; TM: Thematic mapper; TWI: Topographical wetness index; VIF: Variance inflation factors

\section{Acknowledgments}

Authors would like to thanks the inhabitants of Darjeeling District because they have helped a lot during our field visit. The authors would like to give special thanks to two anonymous reviewers for their constructive and useful comments during the review process. Also we would like to cordially thank the Mr. Arnab Chatterjee, Assistant Professor, Department of English, Harishchandrapur College, Pipla, Malda for correcting the grammers and language. At last, authors would like to acknowledge all of the agencies and individuals specially, Survey of India (SOI), Geological Survey of India (GSI) and USGS for obtaining the maps and data required for the study.

\section{Authors' contributions}

Both authors wrote the manuscript and developed the research methodology. Both authors also read and approved the final manuscript.

\section{Funding}

No funding was received for this work.

\section{Availability of data and materials}

Rainfall and Temperature were received from Indian metrological Department. Population data was collected from District Statistical Handbook, Census of India 2011. Landsat images and DEM will freely be availed from https:// earthexplorer.usgs.gov/ website. Soil map was collected from National Bureau of Soil Survey and Land Use Planning. Geology map was taken from Geological Survey of India.

\section{Competing interests}

The authors declare that they have no competing interests.

Received: 23 November 2018 Accepted: 15 July 2019

Published online: 01 August 2019

\section{References}

Abedini, M., and S. Tulabi. 2018. Assessing LNRF, FR, and AHP models in landslide susceptibility mapping index: A comparative study of Nojian watershed in Lorestan province, Iran. Environmental Earth Sciences 77 (11): 405.

Aleotti, P., and R. Chowdhury. 1999. Landslide hazard assessment: Summary review and new perspectives. Bulletin of Engineering Geology and the Environment 58 (1): 21-44. https://doi.org/10.1007/s100640050066.

Arnone, E., A. Francipane, A. Scarbaci, C. Puglisi, and L.V. Noto. 2016. Effect of raster resolution and polygon-conversion algorithm on landslide susceptibility mapping. Environmental Modelling \& Software 84: 467-481 https://doi.org/10.1016/j.envsoft.2016.07.016.

Ayalew, L., and H. Yamagishi. 2005. The application of GIS-based logistic regression for landslide susceptibility mapping in the Kakuda-Yahiko Mountains, Central Japan. Geomorphology 65 (1-2): 15-31. https://doi.org/1 0.1016/j.geomorph.2004.06.010. 
Bhandari, R.K. 2004. Landslide hazard zonation: Some thoughts. In Coping with natural hazards: Indian context, ed. K.S. Valdiya, 134-152. Orient Longman: Hyderabad

Bouma, N., and A. Imeson. 2000. Investigation of relationships between measured field indicators and erosion processes on badland surfaces at Petrer, Spain. Catena 40 (2): 147-171. https://doi.org/10.1016/s0341-8162(99)00046-6.

Budimir, M.E.A., P.M. Atkinson, and H.G. Lewis. 2015. A systematic review of landslide probability mapping using logistic regression. Landslides 12 (3): 419-436.

Can, T., H.A. Nefeslioglu, C. Gokceoglu, H. Sonmez, and T.Y. Duman. 2005. Susceptibility assessments of shallow earthflows triggered by heavy rainfall at three catchments by logistic regression analyses. Geomorphology 72 (1-4): 250-271. https://doi.org/10.1016/j.geomorph.2005.05.011.

Chung, C., and A.G. Fabbri. 2003. Validation of spatial prediction models for landslide Hazard mapping. Natural Hazards 30 (3): 451-472. https://doi.org/1 0.1023/b:nhaz.0000007172.62651.2b.

Malley, L.O. 1999. Bengal district gazetteer: Darjeeling, Government of West Bengal. pp. 2-22

District Statistical Handbook 2013. Bureau of Applied Economics and Statistics, Department of Statistics \& Programme Implementation. Government of West Bengal, Kolkata.

Dormann, C.F., J. Elith, S. Bacher, C. Buchmann, G. Carl, G. Carré, J.R.G. Marquéz, B. Gruber, B. Lafourcade, P.J. Leitão, T. Münkemüller, C. McClean, P.E. Osborne, B. Reineking, B. Schröder, A.K. Skidmore, D. Zurell, and S. Lautenbach. 2012. Collinearity: A review of methods to deal with it and a simulation study evaluating their performance. Ecography 36: 27-46 https://doi.org/10.1111/ j.1600-0587.2012.07348.x.

Dou, J., A.P. Yunus, D.T. Bui, A. Merghadi, M. Sahana, Z. Zhu, et al. 2019 Assessment of advanced random forest and decision tree algorithms for modeling rainfall-induced landslide susceptibility in the Izu-Oshima Volcanic Island, Japan. Science of the Total Environment 662: 332-346.

Fan, X., G. Scaringi, G. Domènech, F. Yang, X. Guo, L. Dai, et al. 2019. Two multitemporal datasets that track the enhanced landsliding after the 2008 Wenchuan earthquake. Earth System Science Data 11 (1): 35-55.

Feizizadeh, B., and T. Blaschke. 2011. Landslide risk assessment based on GIS multi-criteria evaluation: A case study Boston Abad county, Iran. Journal of Earth Science and Engineering 1: 66-71.

Feizizadeh, B., and T. Blaschke. 2013. GIS-multicriteria decision analysis for landslide susceptibility mapping: Comparing three methods for the Urmia lake basin, Iran. Natural Hazards 65 (3): 2105-2128.

Feizizadeh, B., M.S. Roodposhti, P. Jankowski, and T. Blaschke. 2014. A GIS-based extended fuzzy multi-criteria evaluation for landslide susceptibility mapping. Computers \& Geosciences 73: 208-221. https://doi.org/10.1016/j.cageo.2014.08.001.

Garcia-Rodriguez, M.J., J.A. Malpica, and B. Benito. 2008. Susceptibility assessment of earthquake-triggered landslides in El Salvador using logistic regression. Geomorphology 95: 172-191. https://doi.org/10.1016/j.geomorph.2007.06.001.

Gerrard, J. 1994. The landslide hazard in the imalayas: Geological control and human action. Geomorphology 10: 221-230

Gupta, R., and B. Joshi. 1990. Landslide hazard zoning using the GIS approach-A case study from the Ramganga catchment, Himalayas. Engineering Geology 28 (1-2): 119-131. https://doi.org/10.1016/0013-7952(90)90037-2.

Guzzetti, F., P. Reichenbach, F. Ardizzone, M. Cardinali, and M. Galli. 2006. Estimating the quality of landslide susceptibility models. Geomorphology 81 (1-2): 166-184. https://doi.org/10.1016/j.geomorph.2006.04.007.

Hejazi, S.A. 2015. Landslide hazard mapping in Goijabel of Ahar using GIS. J Geogr Plan 18 (20): 135-152

Hembram, T.K., and S. Saha. 2018. Prioritization of sub-watersheds for soil erosion based on morphometric attributes using fuzzy AHP and compound factor in Jainti River basin, Jharkhand, eastern India. Environment Development and Sustainability: 1-28. https://doi.org/10.1007/ s10668-018-0247-3.

Malczewski, J. 1999. GIS and multicriteria decision analysis. New York: Wiley.

Malik, R., S. Ghosh, S. Dhar, P. Singh, and M. Singh. 2016. GIS based landslide hazard from zonation along national highway AY-58, from Rishikesh to Joshimath, Uttarkhand, India. International Journal of Advanced Remote Sensing Geography 4 (2): 41-55.

Mallick, J., R.K. Singh, M.A. Alawadh, S. Islam, R.A. Khan, and M.N. Qureshi. 2018. GIS-based landslide susceptibility evaluation using fuzzy-AHP multicriteria decision-making techniques in the Abha watershed, Saudi Arabia. Environmental Earth Sciences 77 (7). https://doi.org/10.1007/ s12665-018-7451-1.
Mcbratney, A., and I.O. Odeh. 1997. Application of fuzzy sets in soil science: Fuzzy logic, fuzzy measurements and fuzzy decisions. Geoderma 77 (2-4): 85-113. https://doi.org/10.1016/s0016-7061(97)00017-7.

Mirnazari, J., S. Khezri, and H. Shahabi. 2015. Assessment and zoning of landslide hazard using AHP model and fuzzy logic operators in Posht tang watershed of Sar pole Zahab (Kermanshah province). Geography and Development 12 (37): 53-70.

Mohammadi, A.T., A. Irani, and J. Sorur. 2014. The preparation of landslide map by landslide numerical risk factor (LNRF) model and geographic information system (GIS). The Egyptian Journal of Remote Sensing and Space Science 17 (2): 159-170.

Mokarram, M., and A.R. Zarei. 2018. Landslide susceptibility mapping using fuzzyAHP. Geotechnical and Geological Engineering. https://doi.org/10.1007/s10706018-0583-y.

Moore, I.D., R.B. Grayson, and A.R. Ladson. 1991. Digital terrain modelling: A review of hydrological, geomorphological, and biological applications. Hydrological Processes 5 (1): 3-30. https://doi.org/10.1002/hyp.3360050103.

Mosavi, S.M., M. Abedini, A. Esmali, and F. Madani. 2017. Landslide hazard zonation by using fuzzy MCDM models in the GIS (case study: Izeh urban watersheds of Khuzestan). Journal of Watershed Management Research 7 (14): 87-78. https://doi.org/10.29252/jwmr.7.14.87.

Negnevitsky, M. 2002. Artificial intelligence: A guide to intelligent systems, AddisonWesley/Pearson education. Harlow.

Panikkar, S.V., and V. Subramanyan. 1996. A geomorphic evaluation of the landslides around Dehradun and Mussoorie, Uttar Pradesh, India. Geomorphology 15: 169-181.

Pourghasemi, H.R., M. Mohammady, and B. Pradhan. 2012. Landslide susceptibility mapping using index of entropy and conditional probability models in GIS: Safarood Basin, Iran. Catena 97: 71-84. https://doi.org/10.1016/j.catena.2012.05.005.

Pradhan, B. 2013. A comparative study on the predictive ability of the decision tree, support vector machine and neuro-fuzzy models in landslide susceptibility mapping using GIS. Computational Geosciences 51: 350-365 https://doi.org/10.1016/j.cageo.2012.08.023

Pradhan, B., and S. Lee. 2009. Regional landslide susceptibility analysis using backpropagation neural network model at Cameron Highland, Malaysia. Landslides 7 (1): 13-30. https://doi.org/10.1007/s10346-009-0183-2.

Pradhan, B., and S. Lee. 2010. Delineation of landslide hazard areas on Penang Island, Malaysia, by using frequency ratio, logistic regression, and artificial neural network models. Environmental Earth Sciences 60 (5): 1037-1054.

Refahi, H.Gh. 2000. Soil Erosion by Water \& Conservation. 2nd ed., Tehran University Publications, Tehran, Iran, pp. 551.

Reichenbach, P., M. Rossi, B.D. Malamud, M. Mihir, and F. Guzzetti. 2018. A review of statistically-based landslide susceptibility models. Earth-Science Reviews 180: 60-91.

Roodposhti, M.S., S. Rahimi, and M.J. Beglou. 2014. PROMETHEE II and fuzzy AHP: An enhanced GIS-based landslide susceptibility mapping. Natural Hazards 73 (1): 77-95.

Saaty, T.L. 1980. The analytical hierarchy process, 350. New York: McGraw Hill.

Saaty, T.L. 1990. The analytic hierarchy process: Planning, priority setting, resource allocation. 1st ed, 502. Pittsburgh: RWS publications.

Saaty, T.L. 1994. Fundamentals of decision making and priority theory with analytic hierarchy process. 1st ed, 527. Pittsburgh: RWS publications.

Saaty, T.L., and L.G. Vargas. 1998. Diagnosis with dependent symptoms: Bayes theorem and the analytic hierarchy process. Operations Research 46 (4): 491-502.

Saha, S. 2017. Groundwater potential mapping using analytical hierarchical process: A study on Md. Bazar block of Birbhum District, West Bengal. Spatial Information Research 25 (4): 615-626. https://doi.org/10.1007/s41324-017-0127-1.

Sarkar, S. 1999. Landslides in Darjiling Himalayas. Transactions Japanese Geomorphological Union 20: 299-315.

Shadfar, S., M. Yamani, and M. Namaki. 2011. Zoning land slide hazard by information value method (IVM), density area (DA) and landslide numerical risk factor (LNRF) model in Chalkrood. Journal of Watershed Management in Engineering 3 (1): 40-47

Tien Bui, D., B. Pradhan, O. Lofman, and I. Revhaug. 2012. Landslide susceptibility assessment in Vietnam using support vector machines, decision tree, and Naïve Bayes models. Mathematical Problems in Engineering 2012: 1-26. https://doi.org/10.1155/2012/974638.

Torkashvand, A.M., A. Irani, and J. Sorur. 2014. The preparation of landslide map by landslide numerical risk factor (LNRF) model and geographic information system (GIS). The Egyptian Journal of Remote Sensing and Space Science 17 (2): 159-170. https://doi.org/10.1016/j.ejrs.2014.08.001. 
Turner, A.K., and L.R. Schuster. 1996. Landslides: Investigation and mitigation. Washington, DC: National Academy Press.

Van Eynde, E., S. Dondeyne, M. Isabirye, J. Deckers, and J. Poesen. 2017. Impact of landslides on soil characteristics: Implications for estimating their age. Catena. https://doi.org/10.1016/j.catena.2017.05.003

Van Westen, C.J., R. Soeters, and K. Sijmons. 2000. Digital geomorphological landslide hazard mapping of the Alpago area, Italy. International Journal of Applied Earth Observation and Geoinformation 2: 51-60.

Wang, H., G. Wang, F. Wang, K. Sassa, and Y. Chen. 2008. Probabilistic modeling of seismically triggered landslides using Monte Carlo simulations. Landslides 5: 387-395. https://doi.org/10.1007/s10346-008-0131-6.

Yesilnacar, E.K. 2005. The application of computational intelligence to landslide susceptibility mapping in Turkey, PhD Thesis, 423. Australia: University of Melbourne.

Youssef, A.M., M. Al-kathery, and B. Pradhan. 2014. Landslide susceptibility mapping at Al-Hasher Area, Jizan (Saudi Arabia) using GIS based frequency ratio and index of entropy models. Geosciences Journal. https://doi.org/10.1 007/s12303-014-0032-8

Zadeh, L.A. 1965. Fuzzy sets. Information and Control 8 (3): 338-353.

Zêzere, J.L., S. Pereira, R. Melo, S.C. Oliveira, and R.A. Garcia. 2017. Mapping landslide susceptibility using data-driven methods. Science of the Total Environment 589: 250-267.

\section{Publisher's Note}

Springer Nature remains neutral with regard to jurisdictional claims in published maps and institutional affiliations.

\section{Submit your manuscript to a SpringerOpen ${ }^{\circ}$ journal and benefit from:}

- Convenient online submission

- Rigorous peer review

- Open access: articles freely available online

- High visibility within the field

- Retaining the copyright to your article

Submit your next manuscript at $\boldsymbol{\nabla}$ springeropen.com 